\title{
Thin Capitalization Rules in EU Member States
}

UDK: 336.221 .4

\section{Tatjana Đukić}

University of Ljubljana, Faculty of Administration

tatjana.dukic@fu.uni-li.si

\section{ABSTRACT}

Thin capitalization rules fit in the group of the specific anti-avoidance rules (SAAR) which are legalised by domestic tax laws. Anti-avoidance measures attempt to strike down unacceptable tax avoidance practices that have taken place with the increasing importance of multinational firms. In contrast to local firms, multinational corporations can shift profits to lower taxed foreign locations, leading to substantial losses in tax revenue. The article presents a systematic review of thin capitalization rules in EU 27, summing up four most common approaches of thin capitalization regulation. The analysis revealed that the majority of countries (15) legalised the fixed ratio approach, one quater (7) the subjective approach and only a few (3) legalised the hidden profit distribution. Two of them have improved thin-cap rules to so called earningstripping rule.

Key words: thin capitalization, tax revenue, anti-avoinance rules, EU, tax authority

\section{JEL: H25}

\section{Introduction}

In the last few years the tax policy of the most developed countries in the world can be described by trend of decreasing tax rates and broadening of tax base for corporate income taxes. This trend has been explained as the reaction of national tax policies on the cross border capital mobility and expanding importance of multinational corporations (Kaserer, 2008).

It is a well established result, both theoretically and empirically; those taxes play an important role in determining the capital structure of 
the companies (Desai et al., 2004). Consequently, a multinational company would choose its capital structure according to differences in international taxation. Unlike purely national firms, multinationals are not restricted to external lending; they can also lend to or to borrow from affiliated companies and are therefore able to optimize their capital structure over all affiliates in order to minimize the tax burden of the whole company group. Especially, they can transform equity into intra-company loans in order to shift profits (Buettner et al., 2006). These kinds of operations are called tax planning activities. Tax planning is the procedure of restructuring business with the intention to decrease tax expenses or increase of tax income with the exact intention to maximize net present value of each business and consequently of the whole company (Jones, 2003).

The tax implications of multinational corporations are the business decisions that decrease tax burden. Those tax planning decisions encourage tax authorities to defend tax revenue by initiating antiavoidance rules. The so called arm's length principle has been adopted in the taxation of multinational companies. The principle is set out in Article 9 of OECD Model Tax Convention and governs the prices at which transfers within a multinational company are set for the purposes of tax. The policymakers and legislators of each country intensively work on different kind of measures and tax systems in order to defend tax revenues and prevent from long-term effects that can be seen as tax competition (Devereux and Keuschnigg, 2009).

The tax theory explains that the appropriate tax system should have two most important criteria: economic efficiency and tax neutrality (Kranjec, 2003). The national tax systems of corporate income taxation should be neutral to business decisions (Stanovnik, 1998). In global economy tax system neutrality is possible only at national level while countries are subject of the tax competition at the international level (Tičar, 2002). There are several reasons why the existence of multinational firms is thought to have an impact on national corporate tax systems. ${ }^{1}$

\section{Thin capitalization rules as anti-avoidance rule}

Corporate income tax (additionally CIT) taxes the net income (profit) of corporation that is computed when all the allowable tax expenses are

1 For a survey on the taxation of multinationals firms see (Gresik, 2001). 
deducted from allowable tax revenues. The literature defines profit as surplus beyond average return on capital that consists of interests, dividends and retained earnings. Profit would present return on capital from the economic point of view under the assumption that all forms of return on capital are treated the same way. Unfortunately, return on debt financing (interests) is treated different way the return on equity financing (dividends) are.

Existing corporate tax systems permit the deduction of interest payments from the corporate tax base, whereas the equity returns to investors are not tax-deductible ${ }^{2}$. This asymmetric treatment of alternative means of financing investment offers firms a fundamental incentive to increase their reliance on debt finance (Haufler and Runkel, 2008). Debt financing has one important advantage under the corporate income tax. The interests that the company pays are tax-deductible expenses while dividends and retained earnings are not. Thus the return to bondholders escapes taxation at the corporate level.

The amount of savings on income tax due to the interest is called interest tax shield. This means that company for every euro paid in the form of interest rather than in the form of dividends, saves the amount of interest multiplied by the corporate income tax rate.

$$
\begin{aligned}
& \text { Interest tax shield }=r^{d} \times(M) \times(t) \\
& r=\text { interest rate on debt financing } \\
& M=\text { amount of debt } \\
& t=\text { income tax rate } \\
& d=\text { interest period }
\end{aligned}
$$

As we can see from the Table 1, if a company pays out or charges interests (debt) it reduces the tax base (profits) and consequently the income tax liability. In doing so, the company generates gains, which can be seen as lower costs or tax liability. For example, in-depth analysis below presents an enterprise operating in the country with 35\% income tax rate evaluating two financial plans. The company $\mathrm{A}$ is financed entirely by equity, while company B has a $\$ 1000.00$ debt, whose cost is $8 \%$.

2 The financial theory explains two way of financing:

a) equity financing (stocks, shares etc.)

b) debt financing (loans, bonds etc.) 
Table 1: The tax deductibility of interests increases the total income that can be paid out to bondholders and stockholders

\begin{tabular}{|l|c|c|}
\hline Statements & $\begin{array}{c}\text { Income statements of } \\
\text { Company A }\end{array}$ & $\begin{array}{c}\text { Income statements of } \\
\text { Company B }\end{array}$ \\
\hline $\begin{array}{l}\text { Earnings before interest and taxes } \\
\text { (EBIT) }\end{array}$ & 1.000 & 1.000 \\
\hline Interests paid to bondholders & 0 & 80 \\
\hline Pre-tax income & 1.000 & 920 \\
\hline Corporate income tax (35\%) & 350 & 322 \\
\hline Net income to stockholders & 650 & 598 \\
\hline $\begin{array}{l}\text { Total income to both (bondholders } \\
\text { and stockholders) }\end{array}$ & $0+650=650$ & $80+598=678$ \\
\hline Interest tax shield (35\% X interest) & 0 & 28 \\
\hline
\end{tabular}

Source: Brealy \& Myers, 2003, p. 490

Analysis of this case highlights two main issues in particular, namely shareholders and bondholders in company B reach a larger scale of cash flow and in the case of increasing the proportion of debt financing compared to equity financing the corporate income tax liability reduces. The difference in the tax burden derives from the fact that interest is tax deductible expense, while dividends and detained or non-distributed profits are not recognized as such.

Because of these positive tax effects of interests, companies prefer debt financing method, which generates tax shield, as we have seen. While on the other hand, too excessive debt financing may possibly lead to financial difficulties and ultimately result in bankruptcy, generating the so-called effect of bankruptcy costs. Companies, which are financed mainly by foreign capital, are faced with more uncertainty compared to companies financed predominantly by equity capital. In the absence of thin capitalization institute the owners of capital are encouraged to preferably lend resources (a loan) as opposed to investing in capital. In this case, owners will be paid interests taxed by the personal tax, while in the first case owners would be subjected to double taxation.

The preferred debt financing is the tax planning activity with clear purpose of tax avoidance. Tax avoidance is any lawful behaviour designed to avoid tax (McLeod, 2000). Tax avoidance transactions tend to have at least one of a number of features that make them identifiable. 
Formal legality, the abuse of statutory loopholes, artificiality, and minimal economic purpose (other than the reduction of tax) are the recurring features of schemes that are seen as instances of tax avoidance (Orow, 2000).

Anti-avoidance measures attempt to strike down unacceptable tax avoidance practices. Tax avoidance, or tax shelters, is a pervasive problem in most of systems. Taxpayers have strong incentives to structure transactions to take advantage of inconsistencies or gaps in the tax rules to reduce their tax liabilities. Virtually all methods of taxation face this problem - inevitably the rules defining the tax base have holes or inconsistencies that can be exploited (Weisbach, 2002). Anti-avoidance measure can be divided into:

- measures based on general principles in the law which are not codified in the legislation but are included in philosophies and approaches in law ("substance over form", "abuse of law"),

- general anti avoidance rules which have the same meaning as "anti avoidance rules based on general principles in law" except that it is codified and included in the legislation

- specific anti avoidance rules which apply to the specific situations; like (CFC - Controlled Foreign Companies, FPI's - Foreign Portfolio Investments, Thin capitalization rules - TCR, Anti-tax haven rules, Transfer pricing).

Typically, high taxing countries try to restrict inter-company loans by imposing the so-called thin capitalization rules or earning stripping rules in order to limit adverse revenue consequences (Overesch \& Wamser, 2006). While debt financing of the parent companies is the preferred way of financing subsidiary companies because of the tax shield, policymakers invented different regulations to prevent tax avoidance in different tax systems ${ }^{3}$. Those regulations are called thin capitalization rules and

3 The European Court of Justice (ECJ) published its decision in the Lankhorst-Hohorst case on 12 December 2002. The case concerned a German taxpayer, Lankhorst-Hohorst $\mathrm{GmbH}$, that incurred interest expenses to a Dutch related party (grandparent) on debt in excess of the German safe haven debt-to-equity ratios. Following the disallowance of the expenses by the tax authorities, the case was referred to the ECJ to determine whether the German thin capitalisation provision discriminated against foreign (EU)-owned companies in violation of the EC Treaty. The ECJ confirmed the taxpayer's decision, concluding that the German thin capitalisation provision indeed infringed on the EU parent entities' freedom of establishment, as it was mainly targeted at foreign-owned companies. 
represent the name given to a particular type of international tax planning. Companies that need to fund parent or subsidiary companies in the other jurisdictions often find it more tax-efficient to fund those subsidiaries with shareholder debt, rather than with equity. The interest on loans from shareholders is deductable in the hands of the borrowing company, while normal dividends are not. There is therefore a tax advantage for a borrowing company that pays high rates of interest on shareholder loans instead of large dividends. Thin capitalization rules are regulations which limit the corporation issue shares as well as debt, referring to a situation in a firm or company where the higher proportion of funds is from loans and borrowings and not from equity and capital. There is no agreement on what constitutes thin capitalization. Two obvious measures are the debt/equity ratio and the ratio of interest to profits before tax (Maßbaum \& Sureth, 2009).

Despite the fluidity of the thin capitalization concept OECD Model Tax Convention on Income and on Capital from 2008 sets up some ground rules and standards in Article 9 - Associated Enterprises considering thin capitalization and its relations to national legislation as well as international tax treaties. As discussed in the Committee on Fiscal Affairs' Report on Thin Capitalization, ${ }^{4}$ there is interplay between tax treaties and domestic rules on thin capitalization relevant to the scope of the Article 9. The Committee considers that:

a) the Article 9 does not prevent the application of national rules on thin capitalization insofar as their effect is to assimilate the profits of the borrowers to an amount corresponding to the profits which would have accrued in an arm's length situation;

b) the Article 9 is relevant not only in determining whether the rate of interest provided for in a loan contract is an arm's length rate, but also whether a prima facie loan can be regarded as a loan or should be regarded as some other kind of payment, in particular a contribution to equity capital;

c) the application of rules designed to deal with thin capitalization should normally not have the effect of increasing the taxable profits of the relevant domestic enterprise to more than the arm's

4 Adopted by the Council of the OECD on 26 November 1986 and reproduced in Volume II of the loose-leaf version of the OECD Model Tax Convention at page R(4)- 1 . 
length profit, and that this principle should be followed in applying existing tax treaties.

Categorization and classification of thin capitalization rules are conducted rather arbitrary and without regard to supranational tax legislation, while its implementation in practice is subsequently limited to few main approaches (Kaserer, 2008):

- The subjective approach: under this approach the prevailing circumstances are evaluated to determine the terms and nature of the contribution to decide whether debt has been disguised as equity. The test of substance over form may be applied in this case.

- The fixed ratio approach: under this approach the part of interest paid on loans in excess of D/E ratio may either be disallowed as it is or the same may be treated as dividend liable to dividend distribution tax. It may be noted that the disallowance of interest may not reduce the interest income of the creditor and he may have to pay tax on it by including it in his taxable income as interest income.

- The hidden profit distributions: under this approach, the excess interest is treated as dividend and taxed accordingly. The general principles of transfer pricing rules (arm's length principle) may also play a role in this respect.

Besides thin capitalization rules interest deduction is regulated with additional approach:

- The earning-stripping rule: under this approach tax deducted interest expenses are limited not only for related but also unrelated parties.

\section{Thin capitalization rules in EU 27}

The data analysis for the $27 \mathrm{EU}$ members reveals that thin capitalization rules vary considerably among different countries. Anyway, our research outlined few models which are most common in the majority of EU member states. The complexity of the systems in EU 27 does not allow strict distinction of principles mentioned above while the majority of EU member states combine different approaches facilitating the implementation of anti-avoidance rules. Member states rather apply 
the inherent mixture or combination of those principles according to the structure of their tax revenue system and tax authority tradition.

\subsection{The subjective approach}

The Table 2 offers the list of countries that have no specific thin capitalization rules. Generally used principle in this respect is the arm's length principle.

\section{Table 2: The subjective approach}

\begin{tabular}{|l|}
\hline State \\
\hline Cyprus \\
\hline Estonia \\
\hline Finland \\
\hline Malta \\
\hline Slovak Republic \\
\hline Sweden \\
\hline United Kingdom \\
\hline
\end{tabular}

Source: IBFD Tax Research Platform, 2011.

The reason those countries do not regulate specific thin capitalization rules is difficult to reveal. The majority ${ }^{5}$ of them are unattractive for foreign direct investors which may be the reason why policymakers have not had any need for protection national tax revenues. While the figuring out the reasons for the lack of thin capitalization regulation is not the objective of the article, it may be interesting for some further research.

\subsection{The fixed ratio approach}

The fixed ratio approach is the most common way of arranging the deduction of interests as tax expense. In the majority of countries the ratio presents the proportion between debt and equity. In case the debt exceeds a debt/equity ratio, interests calculated of the amount of loans that exceed maximum amount of debt are not tax-deductible expenses as far as corporate income tax is concerned.

5 Average \% of FDI in BDP in Estonia is 80.3 (2004-2009) according to UnctadStat, 2010. 
Table 3: The fixed ratio approach

\begin{tabular}{|c|c|c|}
\hline State & Ratio & Regulation \\
\hline \multirow[t]{2}{*}{ Belgium } & $1: 1$ & $\begin{array}{l}\text { Applies to loans granted by individual directors, shareholders } \\
\text { and non-resident corporate directors to their company. Interest } \\
\text { relating to debt in excess of this ratio is recharacterized as a non- } \\
\text { deductible dividend. Also, the interest rate must not exceed the } \\
\text { market rate. }\end{array}$ \\
\hline & $7: 1$ & $\begin{array}{l}\text { Applies to debt if the creditor (resident or non-resident) is exempt } \\
\text { or taxed at a reduced rate in respect of the interest paid on the } \\
\text { debt. }\end{array}$ \\
\hline Bulgaria & $3: 1$ & $\begin{array}{l}\text { If the interest paid on loans taken from shareholders and third } \\
\text { parties deduction of interest paid on loans taken from } \\
\text { shareholders or third parties is limited to the total amount of } \\
\text { interest income received by the company plus } 75 \% \text { of its positive } \\
\text { financial result (computed without taking into account interest } \\
\text { income and expenses). }\end{array}$ \\
\hline $\begin{array}{l}\text { Czech } \\
\text { Republic }\end{array}$ & $4: 1$ & The ratio for banks and insurance companies is $6: 1$. \\
\hline Denmark & $4: 1$ & $\begin{array}{l}\text { A company can avoid the limitation on the deductibility of its } \\
\text { interest expenses to the extent it substantiates that a similar loan } \\
\text { relationship could exist between unrelated persons. } \\
\text { The deductibility of net financing expenses is limited to a capital } \\
\text { computed by applying a standard rate of } 4.5 \% \text { (for } 2011 \text { ) on the } \\
\text { tax value of the company's business assets as listed in the law. } \\
\text { Expenses below approximately } 2,8 \text { million EUR (for } 2011 \text { ) are } \\
\text { always deductible under this rule. The second limitation is based } \\
\text { on annual profits: the net financing expenses may not exceed } \\
80 \% \text { of the annual taxable profits. }\end{array}$ \\
\hline France & $1,5: 1$ & $\begin{array}{l}\text { The deductibility of interest is limited by the application of a } \\
\text { cumulative three-step test: } \\
\text { - This ratio is determined by comparing the loans from } \\
\text { associated companies with the equity capital of the borrower; } \\
\text { - The total amount of interest paid to associated companies } \\
\text { exceeds } 25 \% \text { of its income (before taxation); } \\
\text { - And the amount of interest paid to associated companies } \\
\text { exceeds the amount of interest received from such associated } \\
\text { companies. }\end{array}$ \\
\hline
\end{tabular}

Continues on the next page 


\begin{tabular}{|c|c|c|}
\hline State & Ratio & Regulation \\
\hline Greece & $3: 1$ & - \\
\hline Hungary & $3: 1$ & This rule does not apply to indebtedness to financial institutions. \\
\hline Latvia & $4: 1$ & $\begin{array}{l}\text { The thin capitalization rule does not apply to interest paid: } \\
\text { - on loans or borrowings from credit institutions resident in } \\
\text { Latvia or elsewhere in the EEA or in a country with which } \\
\text { Latvia has a tax treaty in force, from the World Bank Group, } \\
\text { the Latvian state treasury, the Nordic Investment Bank, the } \\
\text { European Bank for Reconstruction and Development, the } \\
\text { European Investment Bank or the Council of Europe } \\
\text { Development Bank; } \\
\text { - by credit institutions or insurance companies } \\
\text { on loans from financial institutions that (i) are resident in } \\
\text { Latvia, another EEA country or a country having a tax treaty in } \\
\text { force with Latvia, (ii) provide borrowing or financial leasing } \\
\text { services, and (iii) are under the supervision of the regulatory } \\
\text { authorities of their state of residence. }\end{array}$ \\
\hline Lithuania & $4: 1$ & $\begin{array}{l}\text { This rule is not applicable if a taxpayer proves that the same loan } \\
\text { could exist between unrelated parties. Financial institutions } \\
\text { providing leasing services are not affected by this rule. }\end{array}$ \\
\hline Netherlands & $3: 1$ & $\begin{array}{l}\text { Excessively financed company exceeds average annual debt a } \\
3: 1 \text { debt/equity ratio for tax purposes and the excess is greater } \\
\text { than EUR } 500,000 \text {. }\end{array}$ \\
\hline Poland & $3: 1$ & - \\
\hline Romania & $3: 1$ & $\begin{array}{l}\text { Deductible interest is limited to the reference interest rate of the } \\
\text { National Bank of Romania for loans denominated in Romanian } \\
\text { lei and to the prescribed annual interest rate for loans } \\
\text { denominated in a foreign currency ( } 6 \% \text { for } 2010) \text {. Interest } \\
\text { expenses that exceed these limits are not deductible. }\end{array}$ \\
\hline Portugal & $2: 1$ & $\begin{array}{l}\text { Thin capitalization rules do not apply to EU resident entities. } \\
\text { Interest on excessive debt may be deducted, except where the } \\
\text { borrower is a resident of a listed tax haven, if the taxpayer can } \\
\text { prove that the loan conditions are comparable to those agreed } \\
\text { by non-related parties in comparable transactions under the } \\
\text { same circumstances. }\end{array}$ \\
\hline Slovenia & $5: 1$ & $\begin{array}{l}4: 1 \text { from } 2012 \text {. However, if the taxpayer proves that the excess } \\
\text { loan could be granted also by a non-related entity, the thin } \\
\text { capitalization rules do not apply. }\end{array}$ \\
\hline Spain & $3: 1$ & - \\
\hline
\end{tabular}

Source: IBFD Tax Research Plafform, 2011. 


\subsection{The hidden profit distributions}

The hidden profit distribution approach treats the excess interest as dividend and conducts taxation accordingly. Generally used principle in this respect is arm's length principle.

\section{Table 4: The hidden profit distribution}

\begin{tabular}{|l|l|}
\hline State & Exceptions \\
\hline Austria & $\begin{array}{l}\text { The Administrative Court has certain broad and rather liberal guidelines, } \\
\text { which are used to determine whether the equity for commercial purposes } \\
\text { is adequate for the purpose of taxation. If the equity is inadequate, a } \\
\text { portion of the indebtedness to shareholders may be regarded as the } \\
\text { equivalent of shareholders' equity. In addition, interest paid on loans that } \\
\text { are regarded as "disguised capital" will be treated as hidden profit } \\
\text { distribution. Such interest may not be deducted from the taxable income. }\end{array}$ \\
\hline Ireland & $\begin{array}{l}\text { Interest paid to a 75\% non-resident parent or co-subsidiary is disallowed } \\
\text { and deemed to be a dividend in certain cases. This does not apply to } \\
\text { payments made to company's resident in EU Member States, to } \\
\text { companies resident in tax treaty countries, or to companies resident in a } \\
\text { non-treaty country, provided that the payment was made in the ordinary } \\
\text { course of the trade of the paying company and the company elects for the } \\
\text { payment not to be treated as a dividend. In addition, subject to conditions, } \\
\text { the deemed-dividend provision does not apply to payments of interest by } \\
\text { banks to non-resident parent companies. }\end{array}$ \\
\hline Luxemburg \\
$\begin{array}{l}\text { Interest payments may be regarded as hidden profit distributions if the } \\
\text { lending company is a shareholder of the borrowing company. In practice, } \\
\text { the tax administration applies a debt to equity ratio of } 85: 15 \text { for the } \\
\text { holding of participations. }\end{array}$ \\
\hline
\end{tabular}

Source: IBFD Tax Research Plafform, 2011.

\subsection{Earning-stripping rule}

The interest stripping rule is not confined to related-party debt. Interest deductibility beyond a critical threshold is restricted, regardless of whether these interest payments are due to related or unrelated parties. 
Table 5: Earning-stripping rule

\begin{tabular}{|l|l|}
\hline State & Regulation \\
\hline \multirow{5}{*}{ Germany } & $\begin{array}{l}\text { Interest expenses may only be deducted up to 30\% of earnings before } \\
\text { interest, taxes depreciation and amortization (EBITDA). If the interest } \\
\text { expenses do not exceed the interest income derived by the paying } \\
\text { company, they remain deductible. Generally, an additional safe haven of } \\
\text { EUR 3 million is granted for excess interest expenses before the 30\% } \\
\text { barrier applies. Non-deductible interest expenses may be carried forward } \\
\text { indefinitely. With effect from 1 January 2010, unused EBITDA must be } \\
\text { carried forward for a maximum period of 5 years. }\end{array}$ \\
$\begin{array}{l}\text { Interests are fully deductible up to an amount equal to interest income } \\
\text { accrued in the same tax period. Any excess over that amount is deductible } \\
\text { to the extent of 30\% of "gross operating income" (earnings before interest, } \\
\text { taxes, depreciation and amortization, EBITDA). The relevant items are } \\
\text { those resulting from the profit and loss account of the company. For } \\
\text { companies drafting their financial statements pursuant to IAS, the } \\
\text { corresponding items of the profit and loss account are taken into account. }\end{array}$ \\
\hline
\end{tabular}

Source: IBFD Tax Research Plafform, 2011.

\section{Discussion}

The brief summary of important trends in European corporate taxation shows that many EU countries experienced a sharp decline in statutory tax rate which is known as the tax competition. The ability of multinational corporations to shift profits without shifting the real investments encouraged the tax authorities to restrict the deductibility of interest payments which are the preferred way of financing corporations because of the tax shield. To avoid higher proportion of debt relative to equity and mainly to protect national tax revenue, thin capitalization rules were tightened in many EU countries.

Recently, the thin capitalization rules have gained new political attention. Despite thin capitalization rules already being in place, a new debate has started on how to prevent multinational firms from shifting a part of their local tax base from high tax to low tax states by setting up appropriate intra-group financial contracts. As a short term consequence, some states started to redesign their thin capitalization rules. The trend of changes referring to interest deduction or thin capitalization rules has been mainly in restricting the fixed ratio approach, limiting deduction up to a certain threshold or changing thin-capitalization rule into earningstriping rule. 
The most radical legislation changes have been made in Denmark, Germany and Italy. In 2007 Denmark extended its thin capitalization rules by introducing an interest stripping rule where interest payments are only deductible up to $80 \%$ of EBIT, regardless whether the underlying debt is granted by a related party. In 2008 Germany restricted the tax deductibility of interest payments even if the debt holder is an unrelated party while net interest payments are recognized as an expense in the tax computation up to an amount of 30 percent of EBITDA. However, this restriction does not apply to companies with net interest payments up to 1.000.000 euro or companies that are not affiliated. In 2008 also Italy replaced its thin capitalization rule by a rule starting that interest expenses are tax deductible up to an amount of 30 percent of EBITDA regardless of whether the debt is granted by a related or unrelated party.

The analysis of the data and all the information for some EU countries provides us the conclusion that countries are challenged by regulating thin capitalization rules. They are supposed to balance their short-term tax revenue goals against the need to create an attractive FDI environment. Denmark, Germany and Italy have modified their regulations in recent years as they seek to achieve both objectives. Very similar attentions can be observed in France, the United Kingdom and Denmark.

In the majority of above mentioned countries the development of thin capitalization regulations has gone through the phase of limiting the debtto-equity ratio of foreign controlled corporations operating within their borders. It turned out to be in contrast with the foreign neutrality tax doctrine within EU at least what has been the reason for several changes and improvements within the last few years. Countries have found it appropriate to extend the initial debt-to-equity ratio rule on all parties; related and unrelated, to put the limit of interest expenses that are deductible without limitation or to change the rule into earning-stripping rule. The reason for this change is possibility of avoiding thin capitalization rule by substituting related debt by unrelated debt. This is not possible under an interest stripping rule, where the only way to prevent any restriction on interest deductibility is to substitute with equity.

Discussing thin capitalization rules and anti-avoidance rules in general we cannot avoid Council Resolution of 8 June 2010 on coordination of the Controlled Foreign Corporation (CFC) and thin capitalization rules within the European Union. The resolution stresses 
the fact that administrative cooperation can be of key importance in ensuring the effectiveness of anti-abuse measures and underlines the importance of member states' assistance to each other for the purpose of detecting and combating abusive schemes.

We cannot avoid pointing out the concept of CCCTB (Common Consolidated Corporate Tax Base) as the present and future project of EU Commission lasting from 2004. After the veto of Ireland in 2008, the concept has not been realized as Directive, but the European Commission has not stopped its work. Even more, in August 2010 they have published the working paper (TaxudD1/CCCTB/RD $\backslash 004 \backslash$ doclen), prepared to facilitate discussion on possible rules to be included in a possible proposal for a CCCTB Directive.

\section{Conclusion}

The global economy has put a big pressure on national tax systems. With the mobility of business enterprises and capital investment taxation opportunities rise. The transfer pricing as a method for tax avoidance has been under scrutiny. This trend has been recognized with the increase in the adoption of specific thin capitalization rules, particularly amongst EU member states.

The analyses of the specific anti-avoidance measures, thin capitalization rules among $27 \mathrm{EU}$ member states bring us to conclusion that tax authorities have restricted anti-avoidance rules to defend tax revenues in the last couple of years. The countries choose different way to prevent income shifting from high to low tax countries. As discussed in the article, specific anti-avoidance rules are a matter of national legislation. Those rules are mentioned only in Commentary to Article 9 of OECD Model Tax Convention as far as secondary tax jurisdiction is concerned.

The national freedom to regulate deduction of interests encouraged us to analyse the approaches of thin capitalization $27 \mathrm{EU}$ member states have chosen. The data of IBFD Database analysis of $27 \mathrm{EU}$ member states revealed that 15 member states legalized the fixed ratio approach, 3 the hidden profit distribution, 7 the subjective approach and 2 earningstripping rule. The important difference between thin capitalization rules and interest stripping rules rests on the fact that the latter is not confined to related-party debt. Interest deductibility beyond a critical threshold is 
restricted, regardless of whether these interest payments are due to related or unrelated parties.

The comparison of thin capitalization regulations among above mentioned countries presents the trend of tightening thin capitalization rules. Even more, trend in EU 27 is restricting the interest deduction not only for related but also on unrelated countries. This trend means movement from thin capitalization rule to earning-stripping rule.

Although thin capitalization rules and earning striping rules are theoretically suitable to get higher tax revenues, it is unclear whether governments can effectively limit inter-company debt shifting. Nevertheless, restricting those rules may create new obstacles to the free movement of capital in the EU.

It would be very interesting to research the connection between thin capitalization restriction and CIT tax rate in the future.

MSc. Tatjana Đukic graduated at the University of Ljubljana, Faculty of Economics in 2000 and finished her master's studies at the University of Maribor, Faculty of Law in 2007. After working eight years in practice as a tax consultant, she continued her career at the University of Ljubliana, Faculty of Administration. She is assistant in the field of Economics in public administration and active member of Chamber of Tax Advisers. Throughout her work she has been involved in various projects and research work, and collaborating in a number of research groups concerning economics in public administration. Her research interests include public finance, taxes, macroeconomics. 


\section{Literatura in viri}

- Brealy, R. A. \& Myers S. C. (2003). Principles of Corporate Finance. New York: McGraw-Hill.

- Buettner, T., Overesch, M., Schreiber, U. \& Wamser, G. (2006). Taxation and Capital Structure Choice-Evidence from a Panel of Geman Multinationals. Munich: ZEW.

- Council Resolution of 8 June 2010 on coordination of the Controlled Foreign Corporation (CFC) and thin capitalization rules within the European Union, 2010/C 156/01 (2010). Bruxelles: European Commission.

- Desai, M. A., Foley, C. F. \& Hines, J. R. (2004). A multinational perspective on capital structure chice and internal capital markets. The Journal of Finance, 59, 2451-2487.

- Devereux, M. P. \& Keuschnigg, C. (2009). The Distorting arm's length principle. Working Paper 09/7.

- Anti-abuse rules in the CCCTB, Workshop on the Common Consolidated Tax Base (CCCTB), TaxudD 1/CCCTB/RD\004\doclen, 20th October 2010. Bruxelles: European Commission.

- Gresik, T. (2001). The Taxing Task of Taxing Transnationals. Journal of Economic Literature, 39, 800-838.

- Haufler, A. \& Marco R. (2008). Firms financial choice and thin capitalization rules under corporate tax competition. Oxford: Oxford University Centre for Business Taxation.

- Haufler, A. \& Schielderup, G. (2000). Corporate Tax System and Cross Country Profit Shifting. Oxford Economic Papers, 52, 306-325.

- Huizinga, H. \& Nielsen, S. B. (1997). Capital Income and Profit Taxation with Foreign Ownership of Firms. Journal of International Economics, 42, 149-165.

- Jones, S. M. (2003). Principles of Taxation and Investment Planning. New York: McGraw-Hill/Irwin.

- Kaserer, C. (2008). Restricting Interest Deductions in Corporate Tax Systems: its Impact on Investment Decisions and Capital Markets. Munich: CEFS.

- Maßbaum, A. \& Sureth, C. (2009). Thin Capitalization Rules and Enterpreneurial Capital Structure Decisions. Official Open Access Journal of $V H B, 1-23$.

- McLeod, R. (2000). Tax Aviidence Revisited. NZJTLP, 103. 
- Mintz, J. \& Smart, M. (2001). Income Shifting, Investment and Tax Competition: Theory and Evidence form Provincial Taxation in Canada. Munich: CESIFO.

- OECD Model Tax Convention on Income and on Capital, Condensed version - 2008. Amsterdam: IBFD.

- Orow, N. (2000). General Anti-Avoidence Rules: A Comparative International Analysis. Bristol: Jordan Publishing Ltd.

- Overesch, M. \& Wamser, G. (2006). German Inbound Investment, Corporate Tax Planning, and Thin-Capitalization Rules-A Difference-inDifferences Approach.

- Stanovnik, T. (1998). Javne finance. Ljubljana: Ekonomska fakulteta.

- Tičar, B. (2002). Učinkovito poslovanje družb z vidika davčnega načrtovanja. Podjetje in delo, 1648-1660. 


\section{POVZETEK}

\section{INSTITUT TANKE KAPITALIZACIJE V DRŽAVAH EVROPSKE UNIJE}

$\checkmark$ večini razvitih držav bi davčno politiko $v$ zadnjih nekaj letih lahko opisali kot trend zmanjševanja davčnih stopenj ter širjenja davčnih osnov. Takšen trend se opisuje kot reakcija nacionalnih davčnih politik na mednarodno mobilnost kapitala ter naraščajoči pomen mednarodnih podjetii, ki ga imenujemo tudi davčna konkurenca.

Teoretična in praktična dognanja kažejo, da igrajo davki pomembno vlogo v določanju kapitalske strukture podjetii. Obstoječi davčni sistemi omogočajo zmanjševanje davčne osnove za obdavčitev davka od dohodkov pravnih oseb z obračunanimi obrestmi, medtem ko donosi od kapitala niso davčno odbitna postavka. Takšna asimetrična obravnava različnih možnosti financiranja spodbuja podjetja k dolžniškemu načinu financiranja. Dolžniško financiranje ima namreč pomembno prednost glede na lastniško, saj so obresti, ki jih podjetje plačuje za izposojanje finančnih sredstev davčno odbitna postavka pri obdavčitvi dohodkov (dobičkov) podjetii, medtem ko dividende in nerazdeljeni dobički niso. Prihranek pri plačilu davka od dohodkov pravnih oseb, ki ga podjetja dosegajo z izbiro zadolževanja imenujemo obrestni davčni ščit. To pomeni, da podjetje za vsak evro, izplačan za obresti, raje kot za dividende, prihrani znesek obresti pomnožen s stopnjo davka od dohodkov pravnih oseb.

Navkljub dejstvu, da dolžniški način financiranja prinaša pozitivne davčne učinke, pa lahko na drugi strani prinese tudi številne druge težave. Preveč poseganja po dolžniškem financiranju lahko zapelje podjetje $\vee$ finančne težave ter se konča celo z bankrotom, ki zopet generira stroške.

Mednarodna podjetja izbirajo kapitalsko strukturo glede na razlike $v$ mednarodnem obdavčevanju. Za razliko od domačih podjetij imajo mednarodna podjetja večje možnosti zunanjega zadolževanja (tudi zunaj meja), tako da lahko posojajo ali si izposojajo od podružnic in s tem optimizirajo svojo kapitalsko strukturo znotraj skupine, da bi tako minimizirali davčno breme celotne skupine (podjetii). Posebej ugodno deluje na poslovanje mednarodnih podjetij dejstvo, da namesto kapitala uporabljajo posojila med podjetji $v$ skupini $z$ namenom prenašanja dobičkov iz držav z visoko v države z nizko obdavčitvijo. Podjetja, še zlasti 
pa mednarodna, imajo torej možnost, da premikajo dobičke ne da bi selila proizvodnjo, kar imenujemo davčno načrtovanje.

Davčno načrtovanje so najrazličnejše oblike dejanj in postopkov poslovnih prilagajanj s ciljem zmanjševanja davčnih obremenitev ali povečanja davčnih prihodkov z natančnim namenom minimiziranja neto sedanje vrednosti posameznega posla in posledično celotnega podjetja. Tovrstni postopki davčnega načrtovanja spodbujajo davčne uprave, da branijo davčne prihodke z iznajdbo pravil proti davčnemu izogibanju.

Pred leti so evropske države začele pravila tanke kapitalizacije, ki sodijo v skupino posebnih pravil proti davčnemu izogibanju, zaostrovati. Kot izogibanje višjemu razmerju dolga relativno glede na kapital, še zlasti pa z namenom ščitenja nacionalnih davčnih prihodkov, je bilo na ravni EU za obdavčevanje mednarodnih podjetii postavljeno tako imenovano tržno načelo. Načelo je regulirano $\vee 9$. členu Vzorčnega davčnega sporazuma OECD ter pokriva področje cen, po katerih se vršijo transakcije med mednarodnimi podjetji za namene obdavčevanja. Posledično pripravljajo politike ter zakonodajne službe posameznih držav najrazličnejše mere in davčne sisteme, s ciljem da se ubrani davčne prihodke in doseže dolgoročne učinke.

$\checkmark$ zadnjem času so pravila tanke kapitalizacije zasedla posebno mesto zanimanja politike. Poleg že obstoječih pravil se je začela debata o tem, kako preprečiti mednarodnim podjetjem, da bi prenašala dele lokalnih davčnih osnov iz držav z visokimi $v$ države $z$ nizkimi davčnimi stopnjami z ustvarjanjem primernih finančnih pogodb znotraj podjetii $v$ skupini. Kratkoročne posledice slednjega so preoblikovanja nacionalnih pravil tanke kapitalizacije $\vee$ nekaterih državah. Trend teh sprememb se nanaša zlasti na odbitke obresti ali pravila tanke kapitalizacije, ki se spreminjajo bodisi $v$ zaostrovanja razmerja med dolgom in kapitalom, omejevanja odbitka obresti do določene meje ali spremembe pravila tanke kapitalizacije $v$ t.i. "earning-striping rule".

Analiza pravil tanke kapitalizacije med 27 državami EU pripelje do sklepa, da so davčne uprave zaostrile pravila tanke kapitalizacije zaradi zaščite davčnih prihodkov v zadnjih nekaj letih. Vsaka država po svoje se je borila proti premikanju dobičkov iz držav z visoko $v$ države z nizko stopnjo obdavčitve, pri čemer vlada nacionalna svoboda, da vsaka država sama uredi možnosti odbitka obresti kot davčno priznanega odhodka. IBFD-jeva baza podatkov je pokazala, da med 27 državami 
članicami EU, 15 držav regulira fiksno razmerje med dolgom in kapitalom (Belgija, Bolgarija, Češka, Danska, Franciija, Grčija, Madžarska, Latvija, Litva, Nizozemska, Poljska, Romunija, Slovenija, Španija in Portugalska), 3 uporabliajo koncept distribucije skritih dobičkov (Avstrija, Irska in Luksemburg) , 7 ima subjektivni pristop (Ciper, Estonija, Finska, Malta, Slovaška, Anglija ter Švedska), medtem ko 2 državi uporabljata t.i. "earning-striping rule" (Nemčija in Italija). Razlika med tanko kapitalizacijo in t.i. pravilom "earning striping" je $v$ tem, da slednje ni omejeno zgolj na povezane osebe, temveč velja za vse. To pomeni, da so obresti kot davčno odbitna postavka limitirane ne glede na to ali so te obresti posledica izposojanja od povezane ali nepovezane osebe.

Primerjava pravil tanke kapitalizacije $v$ državah EU 27 izkazuje trend zaostrovanja pravil proti davčnemu izogibanju. Celo več, trend kaže omejevanje odhodka iz naslova obresti ne le za povezane, temveč celo za nepovezane osebe.

Največje spremembe so se zgodile na Danskem, v Nemčiji in Italiji. V letu 2007 je Danska zaostrila svoja pravila tanke kapitalizacije tako, da je uzakonila "earning-striping rule", s čimer je omejila zgornjo mejo davčno priznanega odhodka iz naslova obresti na največ $80 \%$ dobičkov pred obrestmi in davki (EBIT), ne glede na dejstvo ali za osnovni dolg jamči povezana oseba. Leta 2008 je Nemčija zaostrila pravila davčnega odbitka obresti tudi v primerih, ko gre za dolg od nepovezane osebe, pri čemer so odhodki iz naslova obresti priznani do največ 1.000 .000 evrov. Podobno je pravila tanke kapitalizacije zaostrila Italija, kjer so odhodki iz naslova obresti davčno odbitna postavka do zneska $30 \%$ dobičkov pred obrestmi, davki in amortizacijo (EBITDA), ne glede na dejstvo, da za dolg jamči povezana ali nepovezana oseba.

Rezultati analize so pokazali, da gredo izzivi na področju davčne politike oz. javnih sredstev za države EU 27 v smeri regulacije pravil tanke kapitalizacije. Treba bo namreč uskladiti cilje kratkoročnih davčnih prihodkov na eni ter potrebe po ustvarjanju okolja za privabljanje neposrednih tujih investicij na drugi strani. Spremembe na področju urejanja pravil proti izogibanju davkom so izkoristile Italija, Nemčija in Danska, ki so sistem preprečevanja izogibanju davkom zaradi dolžniškega financiranja spreminjale s ciljem doseganja obeh zastavljenih ciljev. Podobno se dogaja v Franciii, Veliki Britaniji in na Danskem. 
$\checkmark$ kontekstu primerjave regulacii pravil tanke kapitalizacije med državami EU je treba omeniti Resolucijo Sveta z dne 8. 6. 2010 o koordinaciji kontroliranih tujih podjetij ter pravil tanke kapitalizacije znotraj EU. Resolucija poudarja, da je lahko sodelovanje ključnega pomena pri zagotavljanju učinkovitosti pravil proti davčnemu izogibanju ter poudarja pomembnost medsebojne pomoči držav članic pri ugotavljanju in boju proti zlorabam.

Prav tako je $v$ kontekstu pravil proti davčnemu izogibanju treba omeniti tudi koncept konsolidirane davčne osnove za podjetja, ki je pretekli, vendar tudi prihodnji projekt evropske komisije. Navkljub vetu Irske $k$ predlogu Direktive o konsolidirani davčni osnovi podjetii (CCCTB Directive) v letu 2008 se projekt ni zaključil. Celo več, avgusta 2010 je evropska komisija objavila delovno gradivo (TaxudD1/CCCTB/RD \004\doclen), da bi olajšala razpravo o pravilih, ki naj se vključijo v predlog CCCTB Direktive.

In končno. Navkljub dejstvu, da so pravila tanke kapitalizacije ter t.i. "earning-striping rule" teoretično primerna za pobiranje višjih davčnih prihodkov, ostaja odprto vprašanje ali lahko vlade oz. zakonodajalci učinkovito omejujejo premikanje dobičkov med podjetji oz. med državami. Odprto ostaja namreč vprašanje, ali ne pomeni zaostrovanje pravil proti davčnemu izogibanju oviro za prost pretok kapitala $\vee$ EU. 